\title{
ע Yksin maahan tulleiden alaikäisten turvapaikanhakijoiden selviytymiskyvyn tukeminen ohjaajien näkökulmasta
}

Yksin maahan tulleet alaikäiset turvapaikanhakijat tarvitsevat erityisen vahvaa selviytymiskykyä, sillä he ovat kohdanneet sotaa ja traumaattisia tapahtumia kotimaassaan ja pakomatkallaan. Heillä on myös Suomessa edessään uusia haasteita, kuten raskas turvapaikkaprosessi. Selviytymiskyvyllä eli resilienssillä tarkoitetaan tässä tutkimuksessa yksilön kykyä kohdata vaikeuksia ja selvitä vastoinkäymisistä toimintakykyisenä. Näiden nuorten selviytymiskyvyn tukeminen on avainasemassa heidän kotoutumisensa ja hyvinvointinsa edistämisessä. Tukemisen keinoista tämän ryhmän kohdalla on kuitenkin vain vähän tutkimustietoa.

Tässä tutkimuksessa tarkastellaan yksin maahan tulleiden alaikäisten turvapaikanhakijoiden selviytymiskyvyn tukemista ryhmäkotien ohjaajien näkökulmasta. Aineisto muodostui 19 ohjaajan ryhmähaastatteluista, jotka tehtiin neljässä ryhmäkodissa eri puolilla Suomea. Aineiston laajuus kirjoitettuna oli 62 sivua, jotka analysoitiin laadullisella aineistolähtöisellä sisällönanalyysilla. Tulosten mukaan ohjaajat käyttävät laajasti eri tuen keinoja hyödyntäen ammattitaitoaan, vuorovaikutustaitojaan ja arjen toimintoja ja näkevät myös eri palvelujen, yhteistyötahojen ja sosiaalisen verkoston tarjoavan keinoja turvapaikanhakijalasten ja -nuorten tukemiseen. Tuen keinoista muodostui kolme kehää sisältäen nuoren sisäisen maailman, sosiaalisten suhteiden ja yhteiskunnan rakenteiden tasolla toimivia tekijöitä, jotka toimivat lomittain ja toisiinsa vaikuttaen. Eri tuen keinojen hyödyntäminen kaikilla näillä tasoilla on tarpeen. Tutkimuksen tuottamaa tietoa voidaan hyödyntää tukijärjestelmien kehittämisessä, sillä tiukentunut turvapaikkapolitiikka on johtanut nuorten selviytymisen vaikeutumiseen.

ASIASANAT: resilienssi, turvapaikanhakijat, alaikäiset, ohjaajat, maahanmuutto ANNAMAIJA NAHKIAISOJA, ANNUKKA ISOKOSKI, MEERI KOIVULA

\section{YDINASIAT}

Tutkimusten mukaan yksin maahan tulleet alaikäiset turvapaikanhakijat tarvitsevat vahvaa selviytymiskykyä, jonka tukeminen on mahdollista.

Tässä tutkimuksessa ilmeni, että näiden nuorten ohjaajilla on keinoja tukea heidän selviytymis- kykyään sisäisen maailman, sosiaalisten suhteiden ja yhteiskunnan rakenteiden tasolla.

Tutkimuksen tuottamaa tietoa voidaan hyödyntää yksintulleiden alaikäisten tukijärjestelmien ja ryhmäkotien toiminnan kehittämisessä. 


\section{JOHDANTO}

Vuonna 2015 Eurooppaan pyrkivien pakolaisten määrä nousi rajusti. EU-maissa rekisteröitiin 1,2 miljoonaa turvapaikanhakijaa, joista noin kolmasosa oli lapsia. Ilman huoltajaa saapuneita turvapaikanhakijalapsia rekisteröitiin EU:n alueella vuoden 2015 aikana ennätykselliset 88 300. (1.) Oman kodin ja kotimaan jättäminen liittyy useimmiten sotiin, konflikteihin ja luonnonkatastrofeihin, sekä köyhyyteen (2). Vuoden 2015 aikana myös Suomeen saapui ennätykselliset 32476 turvapaikanhakijaa. Heistä yli 3000 oli ilman huoltajaa saapuneita alaikäisiä turvapaikanhakijoita. Muutos aiempaan oli suuri, kun yksin alaikäisenä saapuneiden turvapaikanhakijoiden määrä 15-kertaistui maassamme. (3.)

Perheenyhdistämiskäytännöt ovat muuttuneet niin, että hyvin harva yksin tullut alaikäinen turvapaikanhakija saa vanhempiansa Suomeen (4). YK:n lastenjärjestö Unicefin tuoreen tutkimuksen mukaan yksikään Pohjoismaa ei ole onnistunut varmistamaan turvapaikanhakijalasten oikeuksien toteutumista vuodesta 2015 alkaen. Suomessa havaittiin vakavia puutteita turvapaikanhakijalasten oikeuksien toteutumisessa, sillä kansainvälistä suojelua hakeva lapsi nähdään maassamme ensisijaisesti turvapaikanhakijana eikä lapsena. (5.)

Vuoden 2015 tilanne nosti turvapaikkakäytännöt yhteiskunnalliseksi keskustelunaiheeksi ja toi samalla esiin tarvetta näyttöön perustuvalle kehittämiselle vastaanottotoiminnassa. Yksin maahan tulleiden alaikäisten turvapaikanhakijoiden kasvaneen määrän vuoksi ryhmäkotiyksiköiden määrä Suomessa kasvoi huomattavasti ja tämän myötä turvapaikanhakijoiden tuen tarve tuli entistä selvemmin esille. Valtioneuvosto käynnisti turvapaikkatilanteessa tapahtuneen muutoksen vuoksi kotoutumis- ja työllistämistoimien uudelleen tarkastelun, koska oleskeluluvan saaneet halutaan saada nopeammin toimivaksi osaksi yhteiskuntaa, koulutukseen ja työhön. Tarkastelussa todetaankin toimivien alkuvaiheen palvelujen ja ohjauksen edistävän eheästi etenevää kotoutumista. (4.) Näiden nuorten parissa työskentelevät ammattilaiset ovat avainasemassa heidän selviytymiskykynsä tukemisessa ja ammattilaisilta saatu tieto ja sen esiin tuominen on tärkeää.
Turvapaikanhakija on henkilö, joka hakee suojelua ja oleskelulupaa vieraasta valtiosta. Yksin maahan tulleilla alaikäisillä turvapaikanhakijoilla tarkoitetaan tässä tutkimuksessa alle 18-vuotiaita ilman huoltajaa saapuneita ryhmäkodissa asuvia lapsia ja nuoria, joiden turvapaikanhakuprosessi on meneillään (tästä lähtien: $y k s i n$ tulleet). (6.) Yksin tulleen turvapaikkaprosessi alkaa lapsen saapumisesta maahan ja turvapaikkahakemuksen jättämisestä. Turvapaikkaprosessiin sisältyy poliisin tai rajavartioviranomaisen tekemä turvapaikkahaastattelu ja Maahanmuuttoviraston tekemä turvapaikkapuhuttelu, joissa turvapaikanhakijat joutuvat muistelemaan traumaattisia tapahtumia niin kotimaastaan, kuin matkaltaan useaan kertaan ja heiltä pyydetään todisteita heihin kohdistuvasta uhasta ja matkareitistään. $(7,8$.) Alaikäiselle, jonka ilmoittamaa ikää epäillään, tehdään iänmääritystestejä. Prosessi on nuorelle monivaiheinen, stressaava ja vaikeasti ymmärrettävä, sisältäen monien eri viranomaisten, kuten sosiaalityöntekijöiden, lääkäreiden, ryhmäkodin työntekijöiden, poliisin ja maahanmuuttoviraston yhteistyötä. Prosessi päättyy turvapaikkapäätöksen tiedoksiantoon. $(2,7$.

Epävarmuus myönteisen turvapaikkapäätöksen saamiseen on viime vuosina lisääntynyt huomattavasti. Vielä vuonna 2015 yksi tuhannesta yksin tulleesta sai kielteisen turvapaikkapäätöksen ja voitiinkin hyvin luottavaisesti sanoa, että lähes kaikki heistä saavat turvapaikan, mutta vuonna 2016 yksi sadasta yksin tulleesta sai kielteisen turvapaikkapäätöksen. $(3,9)$. Tieto kielteisten turvapaikkapäätösten uhasta lisää yksin tulleiden epävarmuutta ja ahdistusta, sekä hankaloittaa selviytymistä ja kiinnittymistä yhteiskuntaan. Oleskeluvan kesto on yleensä neljä vuotta, mutta yksin tulleet ovat saaneet paljon myös lyhyempiä oleskelulupia vain yhdeksi vuodeksi, jonka jälkeen jatkolupa voidaan myöntää 1-4 vuodeksi. (10). Maahanmuuttoviraston linja yksin tulleiden jatkoluvissa vaikuttaa tiukentuneen ja niitä on alettu myöntää usein vain vuodeksi kerrallaan, osalta jopa evätty kokonaan. Turvapaikanhakijoiden onkin entistä hankalampaa saada suojelua Suomesta ja epävarmuus tulevasta saattaa hankaloittaa selviytymistä vuosikausia. Tilanne on vaikea nuorelle itselleen, eikä se myöskään palvele yhteiskunnan etua, sillä turva- 
paikanhakijoiden kokema maasta karkottamisen pelko ja turvapaikkaprosessin pitkä kesto ovat erityisiä riskitekijöitä heidän psyykkiselle hyvinvoinnilleen. (11.) UNICEF toteaa selvityksessään, että Suomessa yksintulleiden turvapaikanhakijalasten asioista voisi vastata eri viranomainen. Lasten oikeuksien toteutumiseksi maahanmuuttoviranomaisen sijaan oikea taho olisi lastensuojeluviranomainen. (5.)

Tutkimusten mukaan yksin tulleilla on paljon voimavaroja ja merkittävää joustavuutta selviytymiskeinoissaan $(12,13)$ ja enemmistö heistä on hyvin selviytymiskykyisiä riippumatta kotimaassa koetuista traumoista (12). Selviytymiskyvyllä eli resilienssillä (eng. resilience) tarkoitetaan yksilön tai yhteisön valmiutta kohdata vaikeuksia sekä joustavuutta ja mukautumiskykyä selviytyä niistä (14). Se on läheisesti yhteydessä terveyden ja hyvinvoinnin käsitteisiin. Tässä tutkimuksessa selviytymiskyvyllä tarkoitetaan yksilön läpi elämän kehittyvää taitoa päästä yli vastoinkäymisistä ja pysyä toimintakykyisenä niiden keskellä. Tämä taito voi kehittyä ja siihen voidaan vaikuttaa (15).

Yksin tulleiden selviytymiskyvyn tukeminen on avainasemassa kotoutumisen ja hyvinvoinnin edistämiseksi. He ovat kokeneet monia vaikeuksia, niin kotimaassaan kuin pakomatkallaan ja turvapaikanhakuprosessi sisältää monia stressiä aiheuttavia tekijöitä, joista selvitäkseen he tarvitsevat vahvaa selviytymiskykyä. Selviytymiskykyyn vaikuttavat yksilön ominaisuudet, perhe ja sosiaaliset resurssit (15). Koska yksin tulleilla ei ole perhettä tukenaan ja heidät on repäisty irti sosiaalisista resursseistaan, heidän tuen tarpeensa on suuri. Selviytymiskyky näyttäytyy elämänhallintana, kontrollina ja integraationa, mitkä olisivat niin yksin tulleiden kuin yhteiskunnankin kannalta toivottavia seurauksia onnistuneesta tuesta vastaanotto- ja kotoutumisprosessin aikana (15).

Traumoille altistuneilla lapsilla on aiemman tutkimustiedon valossa nähtävissä mikro- ja makrotason tuen tarvetta. Mikrotason tuki on sosiaalisten suhteiden ja kommunikaatiotaitojen vahvistamista, sisältäen yksilön vahvuuksien, itseluottamuksen ja kognitiivisten taitojen tukemista. Makrotasolla tuki tarkoittaa erilaisia yhteiskunnallisia tekijöitä kuten talous- ja sosiaalipolitiikan linjaukset, jotka vaikuttavat selviytymiseen myös yhteiskunnan asenteiden ja turvallisuuden kautta.
(16.) Selviytymistä tukevien asumisjärjestelyjen ja kehitysympäristöjen on todettu vähentävän yksin maahan tulleiden oireilua ja edesauttavan suojaavien tekijöiden rakentumista (17). Yksin tulleet alle 16-vuotiaat majoitetaan Suomessa turvapaikanhakuprosessin ajaksi ryhmäkoteihin, joissa he saavat ammatillista hoivaa ja huolenpitoa ja heidän perustarpeistaan huolehditaan. Yli 16-vuotiaat sijoitetaan useimmiten asumaan itsenäisemmin, tuetun asumisen piiriin. Ryhmäkodeissa Maahanmuuttoviraston ohjeistuksen mukaan henkilöstöresurssin ja toiminnan tulisi olla suomalaisten lastensuojelulaitosten kaltaisia. Oleskeluluvan saatuaan lapsi siirtyy asumaan perheryhmäkotiin tai tuettuun asumiseen riippuen iästä ja kyvyistä itsenäiseen elämiseen. $(2,18,19$.)

Peruskouluikäisillä turvapaikanhakijoilla on oikeus ikänsä ja lähtötasonsa mukaiseen opetukseen koulussa $(7,19)$. Lapset saavat myös tarvittaessa oikeudellista apua ja jokaiseen viralliseen tilanteeseen tulkkauspalvelun. Alaikäiselle ilman huoltajaa maassa olevalle turvapaikanhakijalapselle nimetään edustaja, joka valvoo lapsen edun toteutumista ja auttaa lasta viranomaisasioissa ja turvapaikkaprosessiin liittyvissä käytänteissä. $(7,18,19$.) Alaikäisillä turvapaikanhakijoilla on oikeus samoihin sosiaali- ja terveydenhuoltopalveluihin kuin kunnan asukkailla, kuten esimerkiksi lastensuojeluun ja koulu- ja opiskelijaterveydenhuoltoon (20.)

Suomessa käytetään omaohjaajamallia alaikäisten turvapaikanhakijoiden tukemisessa (18). Tässä tutkimuksessa tarkastellaan yksin tulleiden selviytymiskyvyn tukemista ryhmäkotien ohjaajien näkökulmasta. Ohjaajat ovat sosiaalija terveysalan ammattilaisia, jotka vastaavat alaikäisten turvapaikanhakijoiden kasvatustyöstä ja hyvinvoinnista ryhmäkodeissa, ja ovat tiiviisti läsnä heidän arjessaan (18). Heillä on kokemuksellista tietoa ryhmäkotien arjesta, nuorten elämästä, tuen keinoista ja niiden kehittämistarpeista. Ohjaajien näkökulmaa yksin maahan tulleiden tukemisessa ei ole juurikaan tutkittu.

\section{TUTKIMUKSEN TARKOITUS JA TUTKIMUSKYSYMYS}

Tämän tutkimuksen tarkoitus on tuottaa tietoa yksin maahan tulleiden alaikäisten turvapaikanhakijoiden selviytymiskyvyn tukemisesta ryhmäkotien ohjaajien näkökulmasta. Tutkimuksen tuottamaa tietoa voidaan hyödyntää yksin tullei- 
den alaikäisten tukijärjestelmien kehittämiseksi ja erilaisten tukikeinojen käytön mahdollistamiseksi. Tutkimuskysymys oli: Millaisia keinoja ohjaajat näkevät yksin maahan tulleiden alaikäisten turvapaikanhakijoiden selviytymiskyvyn tukemiseen?

\section{AINEISTO JA TUTKIMUSMENETELMÄT}

Aineisto kerättiin temaattisella ryhmähaastattelulla, haastattelemalla neljässä ryhmäkodissa 19 työntekijää, jotka olivat sosiaali- ja terveysalan ammattilaisia ja toimivat tai olivat toimineet yksin maahan tulleiden alaikäisten turvapaikanhakijoiden omaohjaajina. Haastatellut työntekijät työskentelivät yksin tulleiden kanssa, joiden turvapaikanhakuprosessi oli kesken eikä oleskelulupaa oltu vielä myönnetty.

Haastattelujen toteuttamisen aikaan Suomessa toimi kahdeksan ryhmäkotiyksikköä yksin tulleille alaikäisille turvapaikanhakijoille. Yksiköiden valinta tehtiin tarkoituksenmukaisuusperiaatteen mukaan (21.): ensimmäiseksi oltiin yhteydessä toimintansa vakiinnuttaneisiin yksikköihin. Haastattelut tehtiin neljässä yksikössä alueellisesti eri puolilla Suomea joulukuun 2017 ja helmikuun 2018 välisenä aikana.

\section{AINEISTON KERUU JA ANALYYSI}

Haastatteluista sovittiin ryhmäkotiyksiköiden esimiesten kanssa, joiden kautta pyyntö tutkimukseen osallistumisesta välitettiin työntekijöille. Yksikkökohtaiset tutkimusluvat saatiin ennen haastatteluajankohtaa. Ennen haastattelua osallistujat antoivat kirjallisen suostumuksen osallistumiseen ja haastattelun nauhoittamiseen. Osallistujien ja ryhmäkotiyksikön taustatiedot kerättiin erillisillä lomakkeilla teemahaastattelun päätteeksi.

Aineiston keruussa hyödynnettiin temaattisen ryhmähaastattelun keskustelunomaisuutta, jolloin osallistujat toivat monipuolisesti esiin jaettuja näkemyksiä, kokemuksia ja ajatuksia. Osallistujien keskinäinen tuttuus ja jaetut kokemukset työssään mahdollistivat luottamuksellisen ja avoimen vuorovaikutuksen. (22.) Teemahaastattelun avoimien kysymysten pohjana käytettiin Ungarin ym. (23) eri kulttuurikonteksteissa elävien nuorten selviytymiskykyä käsittelevää seitsemän jännitteen mallia. Nämä seitsemän jännitettä ovat aineelliset resurssit, ihmissuhteet, identiteetti, yhteenkuuluvuus, valta ja kontrolli, sosiaalinen oikeudenmukaisuus ja kulttuurinen uskollisuus (23). Teemarunkoa ja kysymysten ymmärrettävyyttä testattiin etukäteen vapaaehtoisryhmällä. Ryhmähaastattelutilanteisiin osallistui kaksi tutkijaa toisen toimiessa moderaattorina ohjaten keskustelua teemakysymysten avulla ja toisen fasilitaattorina huolehtien äänityksestä ja tehden muistiinpanoja. Teemahaastattelulla saatiin monipuolisia kuvauksia tutkittavasta ilmiöstä ja mahdollistettiin keskustelun eteneminen ryhmän ehdoilla. (22.)

Haastattelujen kesto vaihteli $1 \mathrm{~h} 19 \mathrm{~min}-1 \mathrm{~h}$ 30 min välillä ja nauhoitusten litteroinnista kertyi yhteensä 62 sivua tekstiä (Times New Roman, fontti 12 , riviväli 1). Litterointi ja alustavaa analyysia tehtiin lomittain aineistonkeruun kanssa ja näin saatettiin todeta neljännen haastattelun jälkeen aineiston saturoituneen niin, että uudet haastattelut eivät todennäköisesti enää rikastaisi aineistoa (22).

Analyysimenetelmänä käytettiin tutkimuskysymyksen ohjaamana aineistolähtöistä sisällön analyysia. Aineiston analyysi eteni litteroinnin ja aineistoon tutustumisen jälkeen tutkimuskysymykseen vastaavien alkuperäisilmaisujen poimintaan ja pelkistämiseen alkuperäisilmaisujen olennainen sisältö säilyttäen. Analyysin edetessä samankaltaiset pelkistykset ryhmiteltiin, luokiteltiin ja ala- ylä- ja pääluokat nimettiin kattavilla ja kuvaavilla nimillä, antaen aineiston ohjata prosessia. Aineistosta syntyi 1143 pelkistystä, 91 alaluokkaa ja 18 yläluokkaa, jotka jakautuivat kolmeen pääluokkaan. Luokittelun sisäinen johdonmukaisuus varmistettiin kahden tutkijan yhteistyöllä ja liikkumalla vaiheiden välillä edestakaisin analyysin aikana. (24.)

\section{OSALLISTUJIEN JA RYHMÄKOTIEN TAUSTATIEDOT}

Haastateltuja ryhmiä oli neljä, kussakin 4-6 osallistujaa. Osallistujat $(\mathrm{N}=19)$ olivat ryhmäkotien työntekijöitä, joilla oli työkokemusta omaohjaajina neljästä kuukaudesta kolmeenkymmeneenviiteen vuoteen. Heillä oli eri sosiaali- ja terveysalan koulutustaustoja, yksi oli koulutukseltaan opettaja. Osallistujista miehiä oli 7 ja naisia 12, iältään he olivat 23-61-vuotiaita. Jokaisessa haastatteluryhmässä oli yksi äidinkieleltään muun kuin suomenkielinen työntekijä.

Ryhmäkodeista, joissa haastattelut tehtiin, kaksi oli toiminut yli yhdeksän vuotta, muut kaksi oli perustettu syksyllä 2015. Yksiköt olivat 
7-21 paikkaisia, ja osassa toimi saman organisaation sisällä tukiasumisyksikkö, aikuisten vastaanottokeskus tai perheryhmäkoti turvapaikan saaneille. Yksin tulleiden määrä oli laskenut 2015 ruuhkahuipusta: yhdessä yksikössä oli haastatteluhetkellä yksi alaikäinen turvapaikanhakija, muissa 5-9, joiden ikäjakauma oli 12-17 vuotta. Tyttöjä oli 1-2, enemmistö nuorista kaikissa yksiköissä oli poikia. Nuoria oli yksiköissä 3-7 lähtömaasta ja he puhuivat 4-6 äidinkieltä.

\section{TULOKSET}

Ohjaajien mukaan yksin maahan tulleiden alaikäisten turvapaikanhakijoiden selviytymiskyvyn tukeminen muodostui keinoista tukea nuoren sisäisen maailman eheyttä, keinoista tukea nuoren ybteyttä sosiaaliseen ympäristöön ja rakenteellisen tuen keinoista (Kuvio 1).

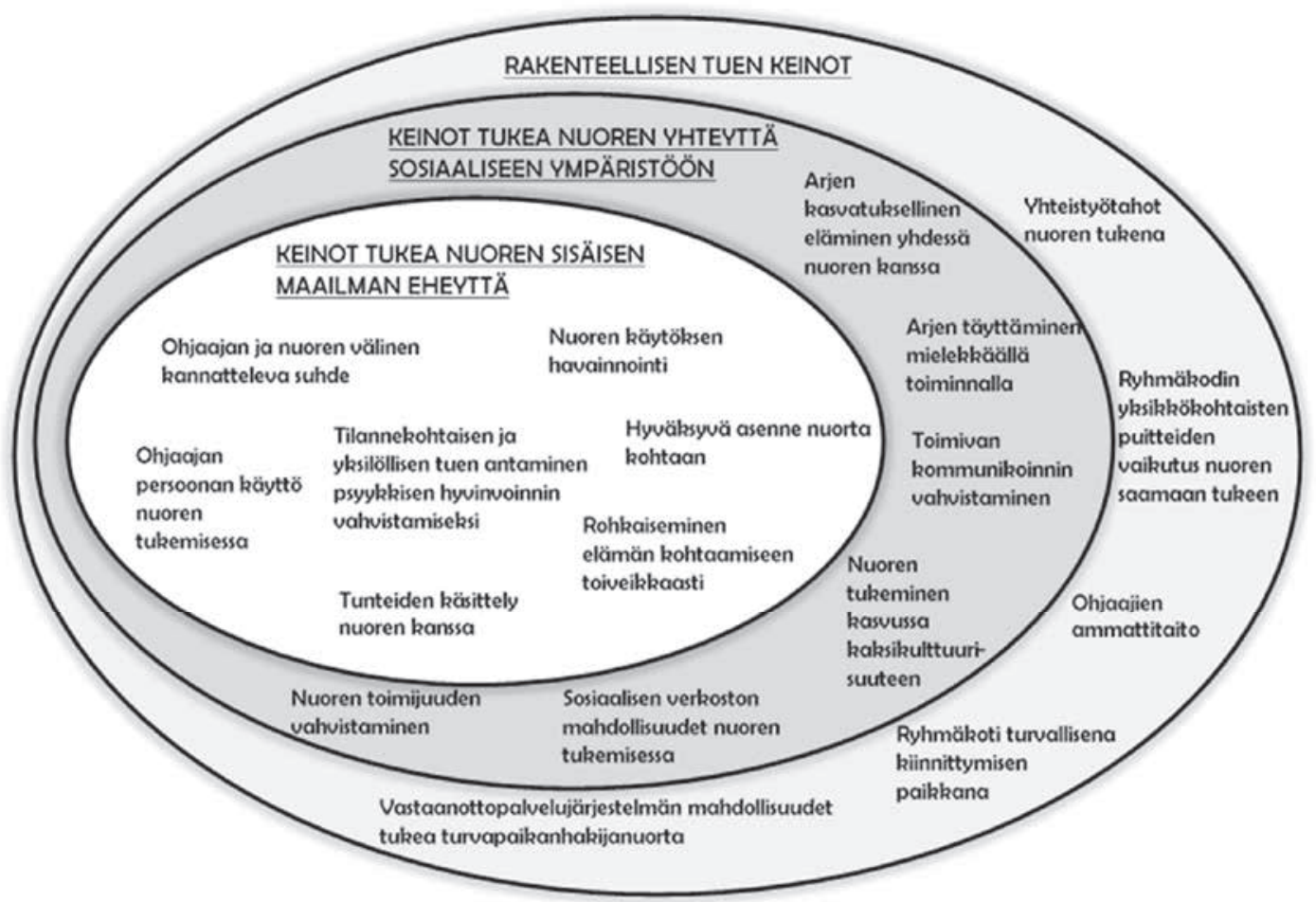

Kuvio 1. Yksin maahan tulleiden alaikäisten turvapaikanhakijoiden selviytymiskyvyn tukeminen

\section{KEINOT TUKEA NUOREN SISÄISEN MAAILMAN EHEYTTÄ}

Objaajan ja nuoren välinen kannatteleva subde oli yhteyden ja luottamuksen saavuttamista, aidon kiinnostuksen osoittamista, tasapuolisuuden kokemuksen vahvistamista ja vastavuoroisuutta ohjaaja-nuori-suhteessa.

"Mä ajattelen, että parhaiten sitä selviytymiskykyä tuetaan sillä, että me luodaan luottamuksellisia subteita, koska se on ollut kyllä koetuksella kotimaassa ja varmasti sen matkan aikana." H2
Nuoren käytöksen havainnointi sisälsi nuoren tunnetilan ja nuoren voinnista kertovien merkkien tarkkailua, nuoren negatiivisten tunteiden ilmaisun tulkintaa luonnolliseksi, ohjaajan intuition hyödyntämistä ja huolen heräämistä nuoresta.

"Ja melkeen on tullutkin semmonen olo, että jos on joku nuori, joka ei ikinä oikein laita vastaan tai osoita olevansa vihainen tai jotakin, niin tulee aina vähän sellanen huoli, että se pitää hirveen paljon itsellään-- Että, okei, että nyt menee ihan hyvin kun pistetään hant- 
tiin, ja niin kun osataan tuua sitä omaa pahaa oloa ulospäin. Silloin pääsee tekemään töitä sen nuoren kanssa." H1

Hyväksyvä asenne nuorta kohtaan tarkoitti myötätuntoista suhtautumista, ennakkoluulottomuutta ja lempeyttä nuorta kohtaan sekä yksilöllisyyden kunnioittamista ja identiteetin rakentumisen tukemista. Ohjaajan persoonan käyttö nuoren tukemisessa sisälsi ohjaajan läsnäolon nuorta varten, ohjaajan käytöksen esimerkkinä nuorelle ja sen, että jokainen ohjaaja oli käytettävissä nuorta varten.

Yksilöllisen tuen antaminen psyykkisen hyvinvoinnin vabvistamiseksi oli traumojen uudelleen aktivoitumisen välttämistä, traumojen käsittelyn mahdollistamista, oikea-aikaista tehostettua tukea ryhmäkodissa, tehostettua tukea nuoren tarpeen mukaan ja tarpeen vaatiessa ryhmäkodin ulkopuolisen lisäavun hankkimista nuorelle.

"Meillä on koulutuskin tulossa koko benkilöstölle, että me tiedetään näistä traumoista enemmän ja pyritään auttaan sitä kautta. Ja viesti nuorille on sellainen, että niitä voidaan käsitellä. Jos ei nyt ole valmis - harva on tässä vaiheessa, kun ei ole kieltä, ei ole tunnekieltä millä pystyis käsittelemään - mutta joskus jatkossa ja luodaan pohjaa sille, että niitä voisi olla hyödyllistä käsitellä, ei ole pakko, mutta se on mahdollista täällä." H2

Ohjaajien keinoja rohkaista elämän kohtaamiseen toiveikkaasti olivat nuoren ohjaaminen elämän rakentamiseen suomalaisessa yhteiskunnassa, kannustaminen ja tukeminen tulevaisuuteen suuntautumisessa. Tunteita käsiteltiin nuoren kanssa nuoren tunteita sanoittamalla, sallimalla negatiiviset tunteet, tukemalla negatiivisten tunteiden purkamiseen toiminnan kautta ja lohduttamalla.

”Kyllä me sitä joillekin tehään - tämmöisille, joilla on se tunteiden hallinta hankalaa, niin kyllähän me lähetään, että me huomataan, että sulla on nyt paha olla. Silleen että: joo et sinä et ole paha vaan sinulla on paha olla. Lähetään tätä kautta, kun monesti sit että 'minä olen hullu tai minä olen tyhmä tai minä olen paha'. Ei, kun se on se tunne vain." H1

\section{KEINOT TUKEA NUOREN YHTEYTTÄ SOSIAALISEEN YMPÄRISTÖÖN}

Ohjaajien keinoja toimivan kommunikoinnin vahvistamisessa olivat keskusteleva tapa käsitellä asioita nuoren kanssa, moninaiset tavat kielimuurin ylittämisessä, suomen kielen kehittymisen tukeminen ja nuoren kuunteleminen tämän ehdoilla.

"...Koittaa kannustaa siihen suomen käyttämiseen ja että sitten kun se nuori vihdoin ja viimein uskaltaa käyttää sitä suomea, niin sitten pitää olla tosi kärsivällinen ja osottaa sille nuorelle, että hei mä haluan tietää, mitä sää haluat sanoa. Niin sit sitäkin kautta voi saada sitä suomen kielen pelkoa vähän alemmas, että sitä sit uskaltaa käyttää.” H1

\section{Arjen kasvatuksellista elämistä yhdessä nuoren} kanssa oli konkreettinen opastaminen yhdessä tekemällä, konkreettinen huolenpito arjessa, kasvatuksellinen työote, auttaminen pärjäämään realiteettien kanssa, tiedon jakaminen elämäntaitojen kehittymiseksi, arjen ja rutiinien sekä arjen selkeiden pelisääntöjen tuoma turva ja motivointi sääntöjen mukaan elämiseen palkintojen ja rangaistusten avulla.

"Sitten kun he tulee tänne, niin beillä on kuitenkin ikätasoansa vastaavat säännöt, mitä me koitetaan noudattaa, mikä on aika vaikeaa välillä. He ei koe sitä sellaisena huolenpitona, vaan rajoittamisena, että heidän vapauksiaan rajoitetaan. Mutta tää on tätä meidän arkee, toki se on sellaista monissa suomalaiskodeissakin." H2

Arjen täyttäminen mielekkäällä toiminnalla sisälsi innostavaa aktivointia toimintaan, järkevän tekemisen tarjoamista, mukavaa yhteistä tekemistä ohjaajan ja nuoren kesken sekä harrastukset nuoren tukena ja koulunkäynti päivien sisältönä.

"Ja sit järjestetään harrastuksia, meillä on yhteistä musiikkitoimintaa, kuntosalivuoroa. Sit myös just mahdollistaa heidän liikkuminen, että he saavat sen bussikortin kuukaudeksi käyttöön. Sit meillä on vimahalli, missä voi käydä nimassa ja kuntosalilla.. Jalkapalloo, mikä on lähes kaikille ykkösjuttu. Et sitä kautta niinku selviytymään ja ne ajatukset pois niistä ikävistä.” H3 
Nuoren tukeminen kasvussa kaksikulttuurisuuteen oli suomalaiseen tapakulttuuriin sopeutumisen tukemista, nuoren oman kulttuurin huomioimista, nuoren uskonnon kunnioittamista ja tukemista kahden kulttuurin välillä.

"Jos yleisesti aattelee, niin on mahdollisuus kaikenlaiseen mahdolliseen oman kulttuurin käyttämiseen, niin se tukee heitä, koska se on sitä pysyvyyttä. Sieltä on tultu ja se ei katoo mihinkään. Että se varmasti heidän olemistaan helpottaa. Tietysti sitten jatkossa he käy niinku sitä, että minkä verran he ottaa sitä suomalaista juttua itsellensä, että kuinka paljon he voi ottaa kadottamatta sitä vanhaa." H4

Nuoren toimijuuden vabvistaminen tarkoitti vaikutusmahdollisuuksien tarjoamista, nuoren osallistamista, itsenäistymistaitojen opettamista ja sosiaalisten taitojen tukemista.

"Mut just nimenomaan yritetään ehkä motivoida sitä kautta, että opiskelu on aina kumminki niinku hyvästä ja että ehkä sais sitten ajatuksia vähän niinku pois. Et kun ne prosessiin liittyvät asiat on sellaisia, mibin ei voi vaikuttaa niin koulu on sellainen asia jobon voi vaikuttaa. ja numeroibin ja tällaisiin.” H3

Sosiaalisen verkoston mahdollisuudet nuoren tukemisessa sisälsivät ohjaajien tuen sosiaalisten suhteiden syntymiseksi, kansallisuusryhmät ryhmäkodilla läheisyyden tunteen lähteenä, paikkakunnan maahanmuuttajaryhmän nuoren yhteisöllisenä tukena ja nuoren ihmissuhteet suomalaisten kanssa merkittävänä tukena.

"Tärkee asia on myöskin, että vaikka olis kuinka hyvät ohjaajat VOKissa (vastaanottokeskus) ja järjestetään mitä vaan, niin se, että he itse löytää koulusta harrastuksista tai jostain muualta näitä suomalaisia oikeita kavereita, jonka luokse voi mennä, jonka kanssa voi sopia pubelimessa ajan, että lähetään kaupungille tai katotaan leffa tai jotain, niin se kyllä selvästi on semmonen iso tekijä." H4

\section{RAKENTEELLISEN TUEN KEINOT}

Objaajien ammattitaitoon liittyi ohjaajien ammatillinen teoriatietämys, ohjauskeinojen rajallisuuden hahmottaminen, ammatillinen näkökulma nuoren kohtaamiseen, ammatillinen kehittyminen sekä kasvatussuunnitelma ja omaohjaajuus ohjaajan työkaluina. Rybmäkoti turvallisena kiinnittymisen paikkana tarkoitti kodin luomista nuorelle ryhmäkodilla, fyysisten tarpeiden täyttämistä, turvallisuuden tunteen tarjoamisen tärkeyttä ja pysyvyyden takaamista asettumisen mahdollistajana.

"Siellä on ehkä alla jo niitä negatiivisia ja ehkä alla jo muutenkin niin epävarmaa se olo ja mibin tässä joutun ja mibin tää johtaa ja jobtaako siihen, että joutuuko palaamaan, niin on se aika hurjaa jos joutuu vielä monta kertaa vaibtaan yksikköäkin.” H3

Ryhmäkodin yksikkökohtaisten puitteiden vaikutus nuoren saamaan tukeen sisälsi tiimityön työyhteisössä, työyhteisön keskinäisen kommunikaation, yksikkökoon ja asiakaskunnan sijoittelun vaikutuksen nuoren selviytymiseen, yksikön toiminnan kehittämisen nuoren tueksi sekä riittävän ohjaajaresurssin, joka mahdollistaa yksilöllisemmän tuen.

”Pienemmässä yksikössä kaikki pubui aika hyvin suomea, kun mä vertasin sitä isompaan yksikköön, niin kyllä siellä oli kielen omaksuminen ihan toista luokkaa. Se johtuu ihan just siitä, kun on liikaa nuoria subteessa benkilökunnan määrään, että sitä yksilöllistä tukea ei saa samalla tavalla kuin sellaisessa kodinomaisessa pienemmässä paikassa.” H4

Yhteistyötahoibin nuoren tukena kuuluivat eri alojen ammattilaiset, koululaitos, vapaaehtoiset toimijat, tukiperheet ja -henkilöt omalla paikallaan nuoren tukena ja mielenterveyspalvelut nuoren apuna.

"Mielenterveystyö nuorisopsykan kanssa. Yhteistyö ylipäänsä, meillä on sosiaaliohjaajaa ja sairaanhoitajaa, edustajaa ja lääkäripalvelut. Kaikki tällaiset on tukimuotoja. Sit kun tuntuu että ne oman keinot ei ei niinku ehkä enää riitä niin on mahdollista ainakin yrittää saada niitä muita." H3 
Ohjaajat arvioivat, että vastaanottopalvelujärjestelmällä olisi muitakin mahdollisuuksia tukea turvapaikanhakijanuorien selviytymistä. Ohjaajien mielestä turvapaikkaprosessin samanaikainen eteneminen samassa ryhmäkodissa asuvien nuorten kesken, mielekkäiden opiskelumahdollisuuksien tarjoaminen peruskouluiän ylittäneille alaikäisille, roolien selkeys eri toimijoiden välillä ja turvapaikkaprosessin pitkittymisen välttäminen auttaisi heitä yksin tulleiden selviytymiskyvyn tukemisessa. Lisäksi selkeä ja pitkäjänteinen linja turvapaikkapäätöksissä vähentäisi nuoren kokemaa epävarmuutta ja nuorten eriarvoisuutta vähentäisi palvelujärjestelmältä saadun tuen yhdenmukaisuus paikkakunnasta riippumatta.

"Mutta yleensäkin tapabtuu niin, että siinä alkuvaiheessa, kun kaikki on tullut, niin niillä on ihan hyvä pössis siinä päällä, mut sitten kun alkaa tuleen lupia, toiset saa oleskeluluvan tai toiset saa negatiivisen, niin se alkaa vaikuttaan sit niihinkin jotka ei oo saanu lupaa, et ne rupee jännittään, että tässähän voi saada kumman vaan, tai miks mulle ei tuu, ja sit siinä vaiheessa alkaa nousta noita mielenterveydellisiä haasteita sitten." H4

\section{YHTEENVETO TULOKSISTA}

Keinoja tukea nuoren sisäisen maailman eheyttä olivat ohjaajan ja nuoren välinen kannatteleva suhde, nuoren käytöksen havainnointi, hyväksyvä asenne nuorta kohtaan ja ohjaajan persoonan käyttö nuoren tukemisessa. Myös yksilöllisen tuen antaminen psyykkisen hyvinvoinnin vahvistamiseksi, rohkaiseminen elämän kohtaamiseen toiveikkaasti ja tunteiden käsittely nuoren kanssa olivat keinoja tukea nuoren sisäisen maailman eheyttä. (Taulukko 1)

Keinoja tukea nuoren ybteyttä sosiaaliseen ympäristöön olivat toimiva kommunikointi ja arjen kasvatuksellinen eläminen yhdessä nuoren kanssa, arjen täyttäminen mielekkäällä toiminnalla, nuoren tukeminen kasvussa kaksikulttuurisuuteen, nuoren toimijuuden vahvistaminen ja sosiaalisen verkoston mahdollisuudet nuoren tukemisessa. (Taulukko 1)

Rakenteellisen tuen keinot sisälsivät ohjaajien ammattitaidon, ryhmäkodin turvallisena kiinnittymisen paikkana, ryhmäkodin yksikkökohtaisten puitteiden vaikutuksen nuoren saamaan tukeen, yhteistyötahot nuoren tukena ja vastaanottopalvelujärjestelmän mahdollisuudet tukea turvapaikanhakijanuorta. (Taulukko 1)

Taulukko 1 Yksin maahan tulleiden alaikäisten turvapaikanhakijoiden selviytymiskyvyn tukemisen keinot

\begin{tabular}{lll}
\hline Pääluokka & Yläluokka & Alaluokka \\
\hline $\begin{array}{l}\text { Keinot tukea } \\
\text { nuoren }\end{array}$ & $\begin{array}{l}\text { Ohjaajan ja nuoren } \\
\text { välinen kannattele- }\end{array}$ & $\begin{array}{l}\text { Yhteyden saavuttaminen } \\
\text { Luottamuksen saavuttaminen } \\
\text { sisäisen }\end{array}$ \\
$\begin{array}{l}\text { va suhde } \\
\text { maailman }\end{array}$ & $\begin{array}{l}\text { Aidon kiinnostuksen osoittaminen } \\
\text { eheyttä }\end{array}$ & $\begin{array}{l}\text { Tasapuolisuuden kokemuksen vahvistaminen } \\
\text { Vastavuoroisuus ohjaaja-nuori-suhteessa }\end{array}$
\end{tabular}

Nuoren käytöksen Nuoren tunnetilan tarkkailu

havainnointi Nuoren voinnista kertovien merkkien tarkkailu

Nuoren negatiivisten tunteiden ilmaisun tulkinta luonnolliseksi

Ohjaajan intuition hyödyntäminen

Huolen herääminen nuoresta

Hyväksyvä asenne Myötätuntoinen suhtautuminen

nuorta kohtaan Ennakkoluulottomuus

Lempeys nuorta kohtaan

Yksilöllisyyden kunnioittaminen

Identiteetin rakentumisen tukeminen

Ohjaajan Ohjaajan läsnäolo nuorta varten

persoonan käyttö Ohjaajan käytös esimerkkinä nuorelle

nuoren tukemisessa Jokainen ohjaaja käytettävissä nuorta varten 
Yksilöllisen tuen antaminen psyykkisen hyvinvoinnin vahvistamiseksi

Rohkaiseminen elämän

Tunteiden käsittely nuoren kanssa

\section{Keinot tukea nuoren yhteyttä sosiaaliseen ympäristöön}

Toimivan

kommunikoinnin

vahvistaminen kohtaamiseen toiveikkaasti

Traumojen uudelleen aktivoitumisen välttäminen

Traumojen käsittelyn mahdollistaminen

Oikea-aikainen tehostettu tuki ryhmäkodissa

Tehostettu tuki nuoren tarpeen mukaan

Tarpeen vaatiessa ryhmäkodin ulkopuolisen lisäavun hankkiminen nuorelle

Nuoren ohjaaminen elämän rakentamiseen suomalaisessa

yhteiskunnassa

Kannustaminen

Tukeminen tulevaisuuteen suuntautumisessa

Nuoren tunteiden sanoittaminen

Negatiivisten tunteiden salliminen

Tukeminen negatiivisten tunteiden purkamiseen toiminnan kautta

Lohduttaminen

Keskusteleva tapa käsitellä asioita nuoren kanssa

Moninaiset tavat kielimuurin ylittämisessä

Suomen kielen kehittymisen tukeminen

Nuoren kuunteleminen tämän ehdoilla

Arjen

kasvatuksellinen

eläminen yhdessä

nuoren kanssa

Konkreettinen opastaminen yhdessä tekemällä

Konkreettinen huolenpito arjessa

Kasvatuksellinen työote

Auttaminen pärjäämään realiteettien kanssa

Tiedon jakaminen elämäntaitojen kehittymiseksi

Arjen ja rutiinien tuoma turva

Arjen selkeiden pelisääntöjen tuoma turva

Motivointi sääntöjen mukaan elämiseen palkintojen ja rangaistusten avulla

Arjen täyttäminen mielekkäällä

toiminnalla

Innostava aktivointi toimintaan

Järkevän tekemisen tarjoaminen

Mukava yhteinen tekeminen ohjaajan ja nuoren kesken

Harrastukset nuoren tukena

Koulu päivien sisältönä

Nuoren tukeminen kasvussa kaksi-

Suomalaiseen tapakulttuuriin sopeutumisen tukeminen

kulttuurisuuteen

Nuoren oman kulttuurin huomioiminen

Nuoren uskonnon kunnioittaminen

Tukeminen kahden kulttuurin välillä

$\begin{array}{ll}\text { Nuoren } & \text { Vaikutusmahdollisuuksien tarjoaminen } \\ \text { toimijuuden } & \text { Nuoren osallistaminen } \\ \text { vahvistaminen } & \text { Itsenäistymistaitojen opettaminen } \\ & \text { Sosiaalisten taitojen tukeminen }\end{array}$

Sosiaalisen Ohjaajien tuki sosiaalisten suhteiden syntymiseksi

verkoston Kansallisuusryhmät ryhmäkodilla läheisyyden tunteen lähteenä

mahdollisuudet Paikkakunnan maahanmuuttajaryhmä nuoren yhteisöllisenä tukena

nuoren tukemisessa Nuoren ihmissuhteet suomalaisten kanssa merkittävänä tukena

$\begin{array}{ll}\text { Rakenteellisen } & \text { Ohjaajien } \\ \text { tuen keinot } & \text { ammattitaito }\end{array}$

Ohjaajien ammatillinen teoriatietämys

Ohjauskeinojen rajallisuuden hahmottaminen

Ammatillinen näkökulma nuoren kohtaamiseen

Ammatillinen kehittyminen

Kasvatussuunnitelma ohjaajan työkaluna

Omaohjaajuus ohjaajan työkaluna 


\begin{tabular}{|c|c|}
\hline $\begin{array}{l}\text { Ryhmäkoti } \\
\text { turvallisena } \\
\text { kiinnittymisen } \\
\text { paikkana }\end{array}$ & $\begin{array}{l}\text { Kodin luominen nuorelle ryhmäkodilla } \\
\text { Fyysisten tarpeiden täyttäminen } \\
\text { Turvallisuuden tunteen tarjoamisen tärkeys } \\
\text { Pysyvyyden takaaminen asettumisen mahdollistajana }\end{array}$ \\
\hline $\begin{array}{l}\text { Ryhmäkodin } \\
\text { yksikkökohtaisten } \\
\text { puitteiden vaikutus } \\
\text { nuoren saamaan } \\
\text { tukeen }\end{array}$ & $\begin{array}{l}\text { Tiimityö työyhteisössä } \\
\text { Työyhteisön keskinäinen kommunikaatio } \\
\text { Yksikkökoon ja asiakaskunnan sijoittelun vaikutus nuoren selviytymiseen } \\
\text { Yksikön toiminnan kehittäminen nuoren tueksi } \\
\text { Riittävä ohjaajaresurssi mahdollistaa yksilöllisemmän tuen }\end{array}$ \\
\hline $\begin{array}{l}\text { Yhteistyötahot } \\
\text { nuoren tukena }\end{array}$ & $\begin{array}{l}\text { Eri alojen ammattilaiset nuoren tukena } \\
\text { Koululaitos nuoren tukena } \\
\text { Vapaaehtoiset toimijat nuoren tukena } \\
\text { Tukiperheet ja -henkilöt omalla paikallaan nuoren tukena } \\
\text { Mielenterveyspalvelut nuoren apuna }\end{array}$ \\
\hline $\begin{array}{l}\text { Vastaanottopalvelu- } \\
\text { järjestelmän } \\
\text { mahdollisuudet } \\
\text { tukea turvapaikan- } \\
\text { hakijanuorta }\end{array}$ & $\begin{array}{l}\text { Turvapaikkaprosessin samanaikainen eteneminen ryhmäkodin } \\
\text { nuorten kesken tukisi selviytymistä } \\
\text { Mielekkäiden opiskelumahdollisuuksien tarjoaminen peruskouluiän } \\
\text { ylittäneille alaikäisille tukisi selviytymistä } \\
\text { Roolien selkeys eri toimijoiden välillä tukisi nuoren selviytymistä } \\
\text { Turvapaikkaprosessin pitkittymisen välttäminen tukisi nuoren } \\
\text { selviytymistä } \\
\text { Selkeä ja pitkäjänteinen linja turvapaikkapäätöksissä vähentäisi } \\
\text { nuoren kokemaa epävarmuutta } \\
\text { Nuorten eriarvoisuutta vähentäisi palvelujärjestelmältä saadun tuen } \\
\text { yhdenmukaisuus paikkakunnasta riippumatta }\end{array}$ \\
\hline
\end{tabular}

\section{POHDINTA}

\section{TULOSTEN TARKASTELUA}

Tutkimuksen tulosten perusteella yksin tulleiden selviytymiskyvyn tukeminen on hyvin monitahoista. Ohjaajat tukevat nuoria arjen käytäntöjen, kasvatuksellisen vuorovaikutussuhteen ja ammattitaitonsa puitteissa. Myös eri palvelujen, yhteistyötahojen ja sosiaalisen verkoston rooli näyttäytyy merkittävänä osana yksin tulleiden tukemisessa. Lisäksi ohjaajat ottivat esille keinoja yhteiskunnallisten rakenteiden tasolla, jotka tukisivat yksin tulleiden selviytymiskykyä, jos niitä kehitettäisiin tai mahdollistettaisiin.

Yksin tulleiden selviytymiskyvyn tukeminen hahmottui ohjaajien näkemyksissä kolmesta lomittaisesta ja toisiinsa vaikuttavasta kehästä, joiden keskiössä on nuori itse (kuvio 1). Sisimmän kehän muodostavat keinot tukea nuoren sisäisen maailman eheyttä, jotka toimivat ohjaajan ja nuoren välisessä suhteessa. Keinot tukea nuoren yhteyttä sosiaaliseen ympäristöön tähtäävät tukiverkoston muodostumiseen nuoren selviytymiskyvyn tueksi niin ryhmäkotiyhteisön kuin koulun ja asuinpaikkakunnan puitteissa. Ulkoinen kehä, rakenteellisen tuen keinot, kattaa yh- teiskunnan mahdollisuudet tarjota tukea ja se luo puitteet niin sisäisen maailman eheyden kuin sosiaalisen yhteyden tukemiseen.

Tutkimus on linjassa kirjallisuudessa esitetyn ajatuksen kanssa mikro- ja makrotason tuen tarpeellisuudesta traumalle altistuneiden lasten selviytymiskyvyn tukemisessa. Makrotasolla yhteiskunnalliset tekijät kuten talous- ja sosiaalipolitiikan linjaukset vaikuttavat selviytymiseen esimerkiksi yhteiskunnan asenteiden ja turvallisuuden kautta. Mikrotason tuki on sosiaalisten suhteiden ja kommunikaatiotaitojen vahvistamista kuten myös yksilön vahvuuksien, itseluottamuksen ja kognitiivisten taitojen tukemista. (16.)

Ohjaajat käyttävät ohjaussuhdetta nuoren sisäisen maailman tukemisessa kannatellen, sanoittaen, havainnoiden ja osoittaen hyväksyntää ja myötätuntoa. Betancourt ja Khan (13) ovat tutkimuksessaan todenneet, että kannattelevan, kannustavan ja turvallisen suhteen luominen edes yhteen aikuiseen tuottaa hyviä lopputuloksia vaikeuksia kohdanneiden lasten kohdalla ja voi vaikuttaa lapsen hyvään kehitykseen jopa suuremmin kuin aikaisemmat traumaattiset kokemukset. Yksin tulleiden tukemisessa korostuu 
kieli- ja kulttuurierojen ylittäminen toimivan suhteen rakentumisessa. Kielimuurin on todettu olevan maahanmuuttajalle suuri stressitekijä ja haaste heidän tukemisessaan (25). Yksin tulleiden kohdalla myös perheettömyys aiheuttaa erityisen tarpeen ja painotuksen ohjaussuhteelle. Ryhmäkodeissa ohjaajat toimivat yksin tulleiden arjen aikuisina ja kasvattajina, ja vertasivatkin työn haasteita tavallisten teini-ikäisten vanhempien kohtaamiin haasteisiin. Nuoren sisäisen maailman tukemisessa yhtenä avaintekijänä on riittävä ohjaajaresurssi, joka mahdollistaa yksilöllisen ja riittävän tuen antamisen yksin tulleille nuorille.

Sekä oman kulttuuritaustan vertaisryhmä, että kantaväestöön kuuluvat ystävät tarjosivat nuorille tukea selviytymiseen. Ohjaajat olivat havainneet harrastusten ja koulunkäynnin edistävän ystävyyssuhteiden syntymistä. Myös aiemmissa tutkimuksissa on todettu koulunkäynnin tärkeys osana yksin tulleen hyvinvointia, sosiaalisten suhteiden luomisessa, kielen oppimisessa ja yhteiskuntaan kiinnittymisessä, kuten myös puitteiden luomisessa nuoren sosiaalisten suhteiden syntymiselle (26). Suomessa oppivelvollisuus päättyy 16-vuotiaana ja tästä johtuen joissakin kunnissa eivät 16 vuotta täyttäneet turvapaikanhakijat enää saa perusopetusta, mikä voi johtaa koulutuksen ja työelämän ulkopuolelle jäämiseen $(5,6)$.

Ohjaajat toivat esiin monia tapoja, joilla yhteiskunnalliset rakenteet tukevat tai voisivat tukea yksin tulleita turvapaikanhakijanuoria. Viime aikoina yhteiskunnallisessa keskustelussa on myös nostettu esiin tarpeita kehittää palvelujärjestelmää niin, että asumisen ja tukisuhteiden jatkuvuus voitaisiin paremmin mahdollistaa turvapaikanhakuprosessin aikana $(6,11)$. Tuloksissa korostui myös tarve eri toimijoiden roolien ja käytäntöjen selkeydelle ja alueellisesti tasa-arvoisille palveluille yksin tulleiden epävarmuuden ja eriarvoisuuden vähentämiseksi. Unicefin selvityksessä (2018) käy ilmi, että Suomessa vuoden 2015 poikkeuksellisen tilanteen myötä käyttöön otetut turvapaikkakäytäntöjen tiukennukset ovat jääneet pysyviksi, jonka johdosta lasten oikeudet eivät pääse toteutumaan (5). Haastatellut ohjaajat olivat kokeneet tiukentuneen turvapaikkapolitiikan vaikeuttavan yksin tulleiden lasten ja nuorten selviytymisen tukemista mm. turvapaikanhakuprosessien venymi- sen, kielteisten turvapaikkapäätösten lisääntymisen ja lyhyiden oleskelulupien vuoksi. Yksin tulleiden selviytymistä ja kiinnittymistä haastoi ohjaajien mukaan myös se, että nuorten palvelut ovat erilaisia kunnasta riippuen ja joidenkin nuorten on pitänyt useita kertoja vaihtaa asumisyksikköä ja jopa asuinpaikkakuntaa. Yksin tulleiden kohdalla on havaittu valitettavan paljon pelkoja ja epävarmuutta aiheuttavia siirtoja, niin turvapaikkaprosessin aikana, kuin oleskeluluvan myöntämisen jälkeenkin (27). Näitä tulisi kaikin keinoin välttää, jotta lapselle saataisiin mahdollistettua ainakin tältä osin turvallinen ja vakaa ympäristö.

\section{TUTKIMUKSEN LUOTETTAVUUS JA EETTISYYS}

Tutkimuksen luotettavuuden kannalta on olennaista, että tiedonantajina kuullaan henkilöitä, joilla on ilmiöstä paras tieto (22). Kirjallisuudessa on todettu turvapaikanhakijoiden haavoittuvuus heitä tutkittaessa, kuten myös haasteet luottamuksen saavuttamisessa ja kommunikoinnissa $(17,28)$. Tässä tutkimuksessa haastateltiin ryhmäkotien ohjaajia, joilla on yksin tulleiden kanssa ryhmäkodin arkea eläneinä ammattilaisina luotettavaa tietoa näiden lasten ja nuorten selviytymiskyvystä ja sen tukemisen keinoista.

Aineiston luotettavuutta lisää sen saturoituminen: vastauksissa ilmeni toistumista, mistä saatettiin päätellä, etteivät lisähaastattelut enää toisi olennaista lisäarvoa (22). Haastattelutilanteissa oli paikalla kaksi tutkija, jonka jälkeen nauhoituksia kuunneltiin useaan kertaan muodostaen yhteisymmärrystä tulkinnasta. Tämä vahvistaa luotettavuutta ja uskollisuutta alkuperäismerkityksille. Koska induktiivisen sisällönanalyysin luotettavuudessa uskollisuus aineistolle korostuu ja aineiston on saatava ohjata analyysia (24), systemaattisuuteen pyrittiin laajan aineiston hallitsemiseksi analyysin eri vaiheissa. Luokittelun loogisuutta tarkastettiin myös takaisin alkuperäisaineistoon päin. Analyysin uskottavuutta vahvistaa tutkijaryhmässä käyty keskustelu luokittelusta ja luokkien nimityksistä (24). Tulosten luotettavuuden arvioinnin mahdollistamiseksi tuloksiin on liitetty näytteitä alkuperäisaineistosta.

Tutkimuksen heikkoutena voidaan pitää ohjaajien näkökulmaa, joka saattaa antaa nuorten tilanteesta todellisuutta myönteisemmän kuvan. Nuorten kokema rasismi tai syrjintä ei noussut 
tutkimusaineistossa esiin. Tämä on hieman yllättävää, sillä tiedetään, että yksin maahan saapuneisiin alaikäisiin on suhtauduttu epäluuloisesti suomalaisessa yhteiskunnassa (vrt. keskustelu ankkurilapsista). Ylipäänsä rasistinen syrjintä on yleistä Suomessa (29). Aiemman tutkimustiedon valossa, syrjintäkokemukset on tärkeä ottaa huomioon nuorten selviytymiskykyä tukiessa, sillä syrjinnällä tiedetään olevan kielteinen yhteys terveyteen ja hyvinvointiin (30). Myöskään kielteisen turvapaikkapäätöksen saaneiden nuorten tukemista ei tässä aineistossa käsitelty.

Tässä tutkimuksessa eettisiä käytänteitä noudatettiin kunnioittamalla osallistujien itsemääräämisoikeutta, huolehtimalla tietosuojasta sekä välttämällä aiheuttamasta haittaa osallistujille ja ryhmäkotien nuorille (31). Tutkimusluvat hankittiin yksikkökohtaisesti ja osallistujille tiedotettiin etukäteen ja kirjallisen suostumuslomakkeen kautta osallistumisen vapaaehtoisuudesta, keskeyttämismahdollisuudesta ja aineiston luottamuksellisesta käsittelystä. Aineiston käsittelyssä on huomioitu anonymiteetin säilyminen sekä osallistujien että ryhmäkotien nuorten suhteen.

\section{JOHTOPÄÄTÖKSET}

Tutkimuksessa tuotettiin uutta tietoa alaikäisten yksin maahan tulleiden turvapaikanhakijoiden selviytymiskyvyn tukemisesta Suomessa ryhmäkotien ohjaajien kuvaamana. Tutkimus osoitti, että ryhmäkotien ohjaajilla on käytössä monipuolisia keinoja yksin tulleiden nuorten selviytymisen tukemiseen. Ohjaajat tukevat ammattitaitonsa pohjalta nuorten sisäisen maailman eheyttä hyväksyvällä ja rohkaisevalla asenteella. Keskeis- tä nuorten selviytymiskyvyn tukemisessa on nuorten ihmissuhteiden edistäminen ja nuorten omien tarpeiden, sekä yksilöllisyyden huomiointi. Tiukentunut turvapaikkapolitiikka on johtanut ohjaajien näkökulmasta nuorten selviytymisen vaikeutumiseen. Turvapaikkaprosessin pitkäjänteisyydellä, eri toimijoiden roolien ja käytäntöjen selkiyttämisellä, sekä palveluihin kaivatulla alueellisella tasa-arvoisuudella voitaisiin tukea sekä yksin maahan tulleita nuoria, että heidän ohjaajiaan.

Tutkimuksen tuottamaa tietoa voidaan hyödyntää yksin tulleiden alaikäisten tukijärjestelmien kehittämisessä, ryhmäkotien henkilökunnan koulutuksessa ja ryhmäkotien johtamisessa. Perusturvallisuuden tunne on erityisen tärkeää yksin tulleiden selviytymiskyvyn kannalta, joten poliittisella tasolla olisi kehitettävä ratkaisuja yksin tulleiden jatkuvuuden tunteen mahdollistamiseksi turvapaikkaprosessin aikana ja sen jälkeen.

Jatkossa tulisi selvittää yksin maahan alaikäisenä tulleiden turvapaikanhakijalasten ja -nuorten selviytymistä pidemmällä aikavälillä, miten heidän kiinnittymisensä yhteiskuntaan sujuu ja mitkä tekijät vaikuttavat siihen.

\section{RAHOITTAJAT:}

Tämän tutkimuksen raportointiin on saatu kilpailutettua valtion tutkimusrahoitusta Pirkanmaan sairaanhoitopiiriltä.

\section{KIRJOITTAJIEN KONTRIBUUTIOT:}

Nahkiaisoja, Isokoski ja Koivula ovat toteuttaneet tutkimuksen suunnittelun ja käsikirjoituksen kirjoittamisen. Nahkiaisoja ja Isokoski ovat toteuttaneet aineistonkeruun ja käsittelyn.

Nahkiaisoja, A., Isokoski, A., Koivula, M. Supporting the resilience of the unaccompanied asylum seeker minors - views of residential care workers. Sosiaalilääketieteellinen aikakauslehti - Journal of Social Medicine 20 I 9: 56: 2 I 6-229.

Unaccompanied minors seeking asylum need strong resilience as they have faced war and traumatizing events in their native country and during their escape. They also encounter new challenges, like the exhausting asylum-seeking process, after arrival in Finland. Resilience is seen here as the capacity of an individual to withstand or recover from adversities without losing their stability. Supporting the resilience of these youngsters is crucial for promoting their adaptation and wellbeing, but there is little research done about methods to support their resilience.

This research studied group home residential care workers' perspectives on supporting the resilience of unaccompanied minors. The data was collected from 19 participants in a group interviews, which were carried out in four group homes in different parts of Finland. The data included 62 written pages, which were analyzed using qualitative inductive content analysis. 
According to the results, care workers use widely different means of support, utilizing their professional- and interaction skills, as well as daily activities. They also perceive that various services, cooperation partners and social networks provide means of support for asylum seeking minors. The support methods function in three interconnected levels: inner world of the youth, social relations and societal structures. Developing and making use of support methods on all these levels is important. The results can be used in developing structural support systems because hardening of the asylum politics has induced the minors' resilience becoming more strained.

Keywords: Resilience, Asylum seekers, Minors, Residential care workers, Immigration

Saapunut 12.11.2018

Hyväksytty 14.04.2019

\section{LÄHTEET}

(1) United Nations High Commisioner for Refugees. Global Trends: Forced displacement in 2015. 2016. Luettu 17.5.2018. http://www.unhcr.org/576408cd7.pdf.

(2) Työ- ja elinkeinoministeriö. Ilman huoltajaa tulleiden alaikäisten turvapaikanhakijoiden vastaanotto ja järjestelmän kehittämistarpeet. 2014. Luettu 17.5.2018.

https://tem.fi/documents/1410877/2859687/

Ilman+huoltajaa+tulleiden+

alaikaisten+turvapaikkahakijoiden+ vastaanotto+05092014.pdf.

(3) Maahanmuuton tunnusluvut 2015.

Helsinki: Euroopan muuttoliikeverkosto, Maahanmuuttovirasto; 2016. Luettu 17.5.2018. http://www.emn.fi/files/1363/EMN_ maahanmuuton_tunnusl_2015_tumma.pdf.

(4) Ministeriöiden välinen kotouttamisen yhteistyöryhmä. Valtion kotouttamisohjelma vuosille 2016-2019 ja Valtion periaatepäätös valtion kotouttamisohjelmasta. Helsinki: Työ- ja elinkeinoministeriö; 2016. Luettu 17.5.2018. http://julkaisut.valtioneuvosto.fi/ handle/10024/79075.

(5) UNICEF Office of Research. Protected on Paper? An analysis of Nordic country responses to asylum-seeking children. 2018. https://unicef. studio.crasman.fi/pub/public/Vaikuttaminen/ Protected+on+Paper.pdf.

(6) Lundqvist K, Tantarimäki S, Halttunen T, Vanhanen S. Esiselvitys alaikäisinä ilman huoltajaa Suomeen tulleiden oleskeluluvan saaneiden tuen ja asumisen hallinnoinnista maakuntauudistuksen jälkeen. 2017. http://urn.fi/URN:ISBN:978-952-327-208-8.

(7) Parsons A. Selvitys lapsen edun toteutumisesta turvapaikanhakija- ja pakolaislapsia koskevissa päätöksissä. Helsinki: Vähemmistövaltuutettu; 2010. https://www.syrjinta.fi/ documents/10181/10850/31685_vv_lapsen etu_2010_paino_verkkoversio.pdf/0b0a71424109-4dfb-b4ad-14de6b5564f5

(8) United Nations High Commissioner for Refugees. Voices of Afghan children - A study on asylum-seeking children in Sweden.

Tukholma; 2010.

http://www.unhcr.org/4c8e24a16.pdf.

(9) Maahanmuuttovirasto. Turvapaikkapäätökset:

Yksintulleet alaikäiset, 1.1.-31.12.2016.

2017. Luettu 17.5.2018. https://migri.fi/ documents/5202425/6162987/65766_Tppaatokset_alaikaiset_2016.pdf.

(10) Maahanmuuttovirasto. Jatkolupa yksintulleille alaikäisille myönnetään tällä hetkellä yleensä 2 vuodeksi. Lehdistötiedote. 2018. Luettu 17.5.2018. https://migri.fi/artikkeli/-/asset publisher/jatkolupa-yksintulleille-alaikaisillemyonnetaan-talla-hetkella-yleensa-2-vuodeksi.

Lastensuojelun Keskusliitto. Eikö ilman huoltajaa turvapaikanhakijoina tulleita haluta Suomeen? Kannanotto. 2018. Luettu 22.5.2018. https://www.lskl.fi/materiaali/

(12) Kohli RKS. The sound of silence: listening to what unaccompanied asylum-seeking children say and do not say. British Journal of Social Work 2006;36(5):707-721. https://doi.org/10.1093/bjsw/bch305

(13) Betancourt TS, Khan KT. The mental health of children affected by armed conflict: Protective processes and pathways to resilience. International Review of Psychiatry 2008;20(3):317-328. doi: 10.1080/09540260802090363.

(14) Stevenson A, Stevenson A. Oxford dictionary of English. 3rd ed ed. Oxford: Oxford University Press; 2011.

(15) Caldeira S, Timmins F. Resilience: synthesis of concept analyses and contribution to nursing classifications. International nursing review 2016;63(2):191-199. doi: 10.1111/inr.12268.

(16) Hornor, Gail, RNC, DNP, CPNP. Resilience. Journal of Pediatric Health Care 2017 2016;31(3):384-390. doi: 10.1016/j.pedhc.2016.09.005.

(17) Fazel M, Dr, Reed RV, MRCPsych, PanterBrick C, Prof, Stein A, Prof. Mental health of displaced and refugee children resettled in highincome countries: risk and protective factors. Lancet, 2012;379(9812):266-282. doi: 10.1016/S0140-6736(11)60051-2. 
(18) Järvinen T, Snellman O, Helenius M. Ilman huoltajaa turvapaikkaa hakevan lapsen edustaminen - tietoa vastaanottokeskuksen toiminnasta ja edustajana toimimisesta. 2014. Luettu 17.5.2018. https://migri.fi/documents/

(19) Käsikirja: Ilman huoltajaa tulleiden alaikäisten psykososiaalinen tukeminen perheryhmäkodissa ja tukiasumisyksikössä. Työ- ja elinkeinoministeriö; 2017 Luettu 17.5.2018. http://julkaisut.valtioneuvosto.fi/ handle/10024/80624.

(20) Seppälä E, Tiittala P.

Turvapaikanhakijoiden neuvola-, koulu- ja opiskelijaterveydenhuoltopalveluiden toteutuminen vuonna 2017. Terveyden ja hyvinvoinnin laitos, Tutkimuksesta tiiviisti, 4. 2018. Luettu 19.2.2019. http://www. julkari.fi/bitstream/handle/10024/136066/ URN_ISBN_978-952-343-076-1. pdf? sequence $=1$ \&isAllowed $=y$

(21) Maahanmuuttovirasto. Toiminnassa olevat alaikäisyksiköt 7.11.2017. 2017. Luettu 7.12.2017. http://www.migri.fi/ download/71640_Alaikaisyksikoiden_ yhteystietoja_5.1.2017.pdf?1b13f97fe-225d588.

(22) Holloway I, Wheeler S. Qualitative research in nursing and healthcare. 3 ed. Chichester: WileyBlackwell; 2009.

(23) Ungar M, Liebenberg L, Boothroyd R, Kwong WM, Lee TY, Leblanc J, et al. The Study of Youth Resilience Across Cultures: Lessons from a Pilot Study of Measurement Development. Research in Human Development 2008;5(3):166-180.

doi: 10.1080/15427600802274019.

(24) Elo S, Kyngäs H. The qualitative content analysis process. Journal of advanced nursing 2008;62(1):107-115. doi: 10.1111/j.1365-2648.2007.04569.x.

(25) El-Awad U, Fathi A, Petermann F, Reinelt T. Promoting Mental Health in Unaccompanied Refugee Minors: Recommendations for Primary Support Programs. Brain Sciences 2017;7(11):146. doi: 10.3390/brainsci7110146.

(26) Oppedal B, Idsoe T. The role of social support in the acculturation and mental health of unaccompanied minor asylum seekers. Scandinavian Journal of Psychology 2015;56(2):203-211. doi: 10.1111/sjop.12194.
(27) Laari H, Rummakko S. Ensisiajisesti lapsia? Nuorten turvapaikanhakijoiden elämää vastaanottovaiheessa -kirjoitussarja. Nuorisotutkimusseura. Luettu 20.2.2019 https://www.nuorisotutkimusseura.fi/images/ tiedostot/nakokulma_38_laari_rummakko.pdf

(28) Halkoaho A, Keränen T. Turvapaikanhakijoihin kohdistuva tutkimus ja sen eettiset haasteet. Sosiaalilääketieteellinen aikakauslehti 2017;54(4):265-268. doi: 10.23990/sa.67755

(29) Being Black in the EU. Second European Union Minorities and Discrimination Survey. European Union Agency for Fundamental Rights. 2018. doi:10.2811/791339

(30) Rask S, Elo I, Koskinen S, Lilja E, Koponen $\mathrm{P}$, Castaneda A. The association between discrimination and health: findings on Russian, Somali and Kurdish origin population in Finland. European Journal of Public Health 2018;28 (5):898-903.

(31) Tutkimuseettinen neuvottelukunta. Humanistisen, yhteiskuntatieteellisen ja käyttäytymistieteellisen tutkimuksen eettiset periaatteet ja ehdotus eettisen ennakkoarvioinnin järjestämiseksi. Helsinki; 2009 Luettu 17.5.2018. http://www.tenk.fi/sites/ tenk.fi/files/eettisetperiaatteet.pdf.

\section{AnNamaija Nahkiaisoja \\ TtM, tutkija \\ Pirkanmaan sairaanhoitopiiri}

\section{ANNUKKa IsOKOsKI}

TtM

Yhteiskuntatieteiden tiedekunta, hoitotiede

Tuntiopettaja

Tampereen ammattikorkeakoulu

MeEri Koivula

yliopiston lehtori, dosentti

Yhteiskuntatieteiden tiedekunta, hoitotiede

Tampereen yliopisto 